\title{
Political Representation of Gender in Nepal
}

\section{Dipendra Bikram Sijapati*}

\begin{abstract}
This paper is based on qualitative methods and discusses women's struggle for equal political participation, currently successful in the political representation of gender in Nepal. The aim of this paper is to examine the establishing equal representation in all sectors of elected government and to find out the inclusive participation of male and female in Nepalese, politics and parliament in together. It is based on completely secondary sources of data through the published in different governmental (election commission, 2074) and non-governmental organization. Nepal has been undergoing tremendous socio-political transformations over the past three decades, unitary to federal and monarchical government to the current republican political system; Nepali women have established themselves as key actors of socio-political changes. Nepali women began their struggle during the Rana Regime and advanced since the 1950s, by engaging both in popular peaceful political movements to armed insurgency and parliamentary competition with their male political counterparts. As a result, latest constitution of Nepal ensured $33 \%$ of seats are guaranteed to the parliaments and all other government positions as well as provision of male-female alternates eat provisions. As a result, from the national and local elections of 2017-18, women have come to occupy 41.8 percent political positions across the country. One of the key factors to ensure higher and meaningful participation of women in politics was these favorable electoral provisions. Women have demonstrated success in achieving higher participation in political positions. However, what has been achieved so far is not enough and continued rigorous action among all actors is essential.
\end{abstract}

Keywords: Women in politics, gender representation, political processes, political participation and parliament

\section{Introduction}

Gender inclusion is defined that the "Gender representation and women empowerment as well as the active participation of women in political, economic, social and cultural life should be promoted. For women to be able to fully exercise their human rights, gender perspectives have to be mainstreamed in all inclusive urban policies UNESCO (2017). Social exclusion is defined by the Department of Economic and Social Affairs of the United Nations as the involuntary exclusion of individuals and groups from society's political, economic and societal processes, which prevents their full participation in the society in which they live. Gender equality and social inclusion are seen as not only a fundamental aspect of human rights and social justice, but also a precondition to improve the development process by putting social concerns at the forefront of interventions. In Nepal, Local Government has long history. It was in existence in ancient time in different forms. The history of local government has evolved since Lichhavi Regime. In that era grass root units of the government were names Gram Panchyat, which was the upper level institution

* Mr. Sijapati is a PhD scholar and assistant professor of Population Studies, Patan Multiple Campus, TU,Nepal 
than 'gram' (Upadhayaya, 1995). Panchali can be considered as an ideal of self-governance. Pradhan was the head of Panchali which was highly respected in the society having close approach to king and performed development tasks along with maintaining rules and regulations in the village.

The Rana's period was a perfect model of absolute authority. The king was virtually caged in palace. The Ranas usurped power to amass wealth and consolidate their hold in all possible manners (Sharma, 1998). In Rana regime there was a system which they followed precious battlement as "Manayajan" Kachari. The jams court was a Panchyat section formed legally in 1983 B.S. in Dang and Deukhuri District. It was local courts first of its kind in the history of Nepal. General members of this court, who at first were elected by the public, would nominate Patwari, the head of the court (Paneru, 2002).

In 1949 two main acts were enforced by the Rana Prime Minister Mohan Shamsher. There were Gram Panchyat Justice Act and Panchyat Act, which delegated the Gram panchyat, the right to make certain extension within a ceiling and also provide some special authority in terms of giving justice and penalizing the criminal (Bista, 1999 \&Paneru, 2002).

After Rana Regime, the historic democracy was established in 1950. Then Panchyat Act 1956 was enforced to ensure reforms and development in the Panchayat/village. In 1960, after the Collapsing the democracy, party less Panchayat system was established, the traditional connotation of Panchayat was the informal countries of elderly and respectable people at the local level settle social or property districts. The Panchyat system consisted of three times hierarchy with the village and Town Panchyat at the grass root level, the district Panchyat at the middle level and the national Panchyat at the central level. For all practice purpose the District Panchyat was considered the local level (Sharma, 1998). There was Zonal Panchyat at the beginning but it was removed with the first amendment to the constitution.

There were different Acts which were acted to strength then and improve the situation of local bodies. These were amended along with time passes. The village, town and district Panchyat acts, 1961-62, Local Administration Plan 1974, integrated Panchyat Development Plan 1976, decentralization Act, 1982 were same acts and other major activities which has great significance in Panchyat period for local government. In 1989, Panchyat was dismissed and multi-party democratic parliamentary system was established, but the Panchyat framework for government was followed as it was with changing the name only village development committee, municipality and district development committee. Later than different provisions have been made to strengthen and promote the local governance system as local bodies ACT 1992, local self-governance bill 1996, ordinance and Amendment of certain laws regarding organization and election of local bodies, 1997 and local self-government bill, 1997. There are different rules and regulations which have been implemented for strengthening the local self-governance institutions. The history of decentralization and local self-governance in Nepal is not long and thus it is not very fascination. As we know, Nepal has had long history of highly centralized system of government and the principle of local government had never been seriously thought over 
the past. Local bodies have been operating as agents or branches of the central government performing its duties and relying heavily on it for administrative, functional and financial support (Thapa, 1998). UNICEF (2011) Gender equality "means that women and men, and girls and boys, enjoy the same rights, resources, opportunities and protections. It does not require that girls and boys, or women and men, be the same, or that they be treated exactly alike." As defined by the United Nations (2013), gender equality refers to the equal rights, responsibilities and opportunities of women and men and girls and boys. Social exclusion is defined by the Department of Economic and Social Affairs of the United Nations as the involuntary exclusion of individuals and groups from society's political, economic and societal processes, which prevents their full participation in the society in which they live. Gender equality and social inclusion are seen as not only a fundamental aspect of human rights and social justice, but also a precondition to improve the development process by putting social concerns at the forefront of interventions. This article is based on establishing the gender representation in all sectors of elected government area and to find the inclusive participation of male and female in Nepalese politics.

\section{Methodology}

This paper developed process, the descriptive research design was used and based the literature review and, secondary sources of data. All available secondary data related with this paper and reports, Nepal Election commission reports (2074) and other journals, articles, constitutional books and books. This means secondary information was collected at multiple sources viz. libraries, Nepal Election Commission, governmental and non-governmental offices to ensure the reliability of this paper. Triangulation of data is a major concern and this research attempts to present qualitative gender des-aggregated data relating to the elected members in local government.

\section{Results}

\section{Women candidates of Nepal}

Table 1: Women participation on government in different periods

\begin{tabular}{|l|l|}
\hline Period & Results for women candidates \\
\hline Lichhavi Period (400 to 750 CE) & $\begin{array}{l}\text { The government were names Gram Panchyat was the upper level institution } \\
\text { than 'gram' (Upadhayaya, 1995). Panchali can be considered as an ideal of } \\
\text { self-governance. Pradhan was the head of Panchali which was highly } \\
\text { respected in the society having close approach to king }\end{array}$ \\
\hline $\begin{array}{l}\text { Malla period (1201-1779) 12th } \\
\text { century to the 18th century } \\
\text { (about 600 years) }\end{array}$ & $\begin{array}{l}\text { This era in the valley is eminent for the various social and economic reforms } \\
\text { such as the 'Sanskritization' of the valley people, new methods of land } \\
\text { measurement and allocation, etc }\end{array}$ \\
\hline $\begin{array}{l}\text { Shah Dynesty (1768 to 28 May } \\
\text { 2008) }\end{array}$ & $\begin{array}{l}\text { Shahs of Gorkha or the Royal House of Gorkha, was the ruling Chaubise } \\
\text { Thakuri dynasty from the India subcontinent and derived from the Gorkha } \\
\text { Kingdom from } 1559 \text { to 1768 and later the nified Kingdom of Nepal from } \\
1768 \text { to 28 May 2008. }\end{array}$ \\
\hline
\end{tabular}




\begin{tabular}{|c|c|}
\hline Rana Regmi (1830-2007 BS) & $\begin{array}{l}\text { The Ranas usurped power to amass wealth and consolidate their hold in all } \\
\text { possible manners (Sharma, 1998). In Rana regime there was a system which } \\
\text { they followed precious battlement as "Manayajan" Kachari. } \\
\text { General members of this court, who at first were elected by the public, would } \\
\text { nominate Patwari, the head of the court (Paneru, 2002). } \\
\text { In } 1949 \text { two main acts were enforced by the Rana Prime Minister Gram } \\
\text { Panchyat Justice Act and Panchyat Act these acts delegated the Gram } \\
\text { panchyat, the right to make certain extension with in a ceiling and also } \\
\text { provide some special authority in terms of giving justice and penalizing the } \\
\text { criminal (Bista, 1999, Paneru, 2002). } \\
\text { Under the leadership of Yogmaya Neupane (1860-1941), Nepali women } \\
\text { began their struggle during the Rana Regime and advanced since the 1950s, } \\
\text { by engaging both in popular peaceful political movements to armed } \\
\text { insurgency and parliamentary competition with their male political } \\
\text { counterparts. }\end{array}$ \\
\hline 1959 Parliamenta & $\begin{array}{l}6 \text { (Six) women contesting in election lost where total } 109 \text { men were elected ( } \\
\text { Suwal,2 013) }\end{array}$ \\
\hline $\begin{array}{l}\text { Rastriya panchayat } 1986 \quad( \\
\text { Legislative) election }\end{array}$ & Out of t \\
\hline Parlimantary, 1991 & $\begin{array}{l}205 \text { legislative representatives only } 7 \text { ( } 3.4 \% \text { ) women were elected (Yemi- } \\
2010 \text { ) }\end{array}$ \\
\hline $\begin{array}{l}\text { Parliamentary and Local Bodies, } \\
1999\end{array}$ & $\begin{array}{l}12 \text { (5.85) of } 205 \text { members of parliaments were women and } 806 \text { (19.4\%) of } \\
\text { total } 4146 \text { local elected representatives were women ( UNESC), (2001) }\end{array}$ \\
\hline Constituent Assembly, 2008 & $\begin{array}{l}30 \text { out of } 240 \text { elected CA members were women of the total } 601 \text { CA members } \\
\text { ( Election commission, 2008) }\end{array}$ \\
\hline Constituent Assembly, 2013 & $\begin{array}{l}\text { Out of } 240 \text { elected candidates total to (4.1\%) candidates were women (Shahi, } \\
\text { 2013). }\end{array}$ \\
\hline
\end{tabular}

Source: Literature Review, 2020.

\section{Armed conflict, the peace agreement, and women's engagement}

Developing countries are of ten prone to civil unrest in comparison to developed countries, because of high poverty rates and inequality, pervasive gender-based discrimination, high unemployment, poor governance, and frequent changes in government (Upreti, 2009; Sharma, 2006). On these grounds, the Communist Party of Nepal (Maoist) [CPN (Maoist)] at the time initiated an armed insurrection in February, 1996 (Yami, 2007). The insurgency created huge destruction: according to the Ministry of Peace and Reconstruction, 17886 people were killed, 1530 were disappeared, 79571 persons were displaced, 3142 persons were abducted, 8935persons were disabled, 9000 women became widows, 620 children became orphans, and the property of 17484 people was damaged, causing the country multi-billion in economic losses" (Upreti et al. 2018: P78). With pressure on all areas of life for the Nepali people, the government and the CPN (Maoist) came to sign a Comprehensive Peace Agreement (CPA) on 21 November 2006 (Upreti, 2009). Consequently, with the promulgation of the new Constitution in September of 2015, the country entered into a Federal Democratic Republic with 7 Provinces and 753 local governments, in which $41 \%$ were women elected at all levels of the new governments. 


\section{Women in the 2006 reinstated parliament}

The 19 days of Jan Andolan II forced King Gyanendra to handover state power to political parties and reinstate the dissolved House of Representatives as per the demand of the agitating political parties. During this time, the rebelling political parties asked the Speaker to organize a parliamentary street meeting, but he favored the King and refused to call a street meeting of Parliament. However, the woman Deputy Speaker ChitraLekha Yadav called the parliament meeting in the street and chaired it. She played a crucial role in reinstating the dissolved parliament (House of Representatives). She has also since played a pivotal role in raising women's issues which added a new dimension to the Nepali women's movement (IDEA,2011).

\section{Women in the 2007 Interim-Constitution}

The interim constitution of Nepal 2063 (2007) under clause (3) of sub-clause (b) includes that political parties shall ensure proportional representation of women, dalit (so-called "untouchables" outside the caste system), oppressed communities/indigenous peoples, "backward regions", Madhesis $^{10}$ and other classes. In addition, it mentions that at least one-third of the total number of candidates nominated shall be women (GoN, 2007). The reinstated legislature Parliament of 2007 saw participation of approximately $17.3 \%$ women from the major political parties demonstrating that women were outnumbered by men, with only 57 women participating out of 330 candidates belonging to the major political parties even after 83 members were added from the CPN, of which 31 were women $37.4 \%$.

Table 2: Women's Participation in the reinstated Legislature Parliament in 2007

\begin{tabular}{|l|l|l|l|}
\hline \multirow{2}{*}{ Party } & \multirow{2}{*}{ Total } & Participation by Women \\
\cline { 3 - 4 } & & Number & Per cent \\
\hline Nepali Congress & 133 & 10 & 7.5 \\
\hline CPN (UML) & 83 & 12 & 14.5 \\
\hline CPN (Maoist) & 83 & 31 & 37.4 \\
\hline Others & 31 & 4 & 12.9 \\
\hline Total & 330 & 57 & 17.3 \\
\hline
\end{tabular}

Source: Election Commission of Nepal, 2074)

\section{Women's participation after 1990}

The new Ordinance Act of 1997 made another provision to increase the participation of women at a local level. This act states that one seat must be served for women in each ward of the Village Development Committee. Due to this compulsory provision about 40,000 female candidates were elected in the local level election of 1997 . This provision really forced all parties to support a female candidate and encouraged women to become involved. Women's political participation at a grass roots level has clearly increased but it is too early to say whether any positive change in the lives of women will come about or whether female politicians will be able to raise women's issues strongly (Ghimire D. 2001). 
The Local Self-Governance Act of 1999 was by far the most progressive Act in terms of devolving authority from central to the local governing bodies. Local governing institutions have some taxation authority at the local level as well as limited judicial authority to tackle local level disputes. However, female representation in local governing institutions has been very limited in Nepal. There was less than 10 percent of women in the District Development Committees (DDC) and Village Development Committees (VDC) combined. Not a single woman is the chair person of a DDC or mayor of any municipality. Out of 3,913 VDCs, there were only 13 chairpersons who were women. On the positive side, one of every five seats in each ward of a VDC and municipality that was reserved for women candidates that has ensured the participation of an additional 36,023 women at the wardlevel governance of VDCs and municipalities.

Table 3: Number of Male and Female Candidates Who Contested and were Elected in the Election of 1991

\begin{tabular}{|l|c|c|c|c|c|c|}
\hline \multicolumn{1}{|c|}{ Sex } & National & Percent & District & Percent & VDC & \% \\
\hline Male & 1264 & 93.4 & 2112 & 99.7 & 101546 & 99.1 \\
\hline Female & 81 & 6.6 & 7 & 0.3 & 956 & 0.9 \\
\hline Total & 1345 & 100 & 2119 & 100 & 102502 & 100 \\
\hline Male & 197 & 96.1 & 1067 & 99.4 & 44321 & 99.5 \\
\hline Female & 8 & 3.9 & 7 & 0.6 & 241 & 0.5 \\
\hline Total & 205 & 100 & 1074 & 100 & 44562 & 100 \\
\hline
\end{tabular}

Source: Gender and Democracy in Nepal, Central Department of Home Science Women's Studies Program TU, 2001.

Nepal local government is also an integral part of the Nepalese governance system. Since adopting a policy of decentralization, local governing bodies have over the years acquired increasingly greater authority in Nepal.

Table 4: Constitution Assembly Members Election 2070, Direct Elected Members

\begin{tabular}{|l|l|l|l|l|l|l|l|}
\hline & \multicolumn{3}{|l|}{ CA Election 2013} & \multicolumn{2}{l|}{ CA Election 2008 } \\
\hline $\begin{array}{l}\text { S. } \\
\text { No }\end{array}$ & Name of Parties & Male & Female & Total & Male & Female & Total \\
\hline 1 & CPL UML Amale & 42 & 42 & 84 & 70 & 38 & 108 \\
\hline 2 & CPL Maoist & 26 & 27 & 53 & 152 & 77 & 229 \\
\hline 3 & Raprapa Nepal & 13 & 11 & 24 & 2 & 2 & 4 \\
\hline 4 & Nepali Congress & 46 & 45 & 91 & 76 & 49 & 115 \\
\hline 5 & CPL UML Marx Bad Lenin Bad & 3 & 3 & 6 & - & - & - \\
\hline 6 & Tarai Madhes Loktantrik & 4 & 3 & 7 & 15 & 6 & 21 \\
\hline 7 & Satbhawan Party & 3 & 2 & 5 & 7 & 2 & 9 \\
\hline 8 & Rastriya Prajatantra Party & 5 & 5 & 10 & 4 & 4 & 8 \\
\hline 9 & Madhesi Janaadhikar Forum loktantric & 5 & 5 & 10 & & & \\
\hline 10 & $\begin{array}{l}\text { Rastriya loktantric rastriya Manch } \\
\text { Tharuhat }\end{array}$ & 1 & 0 & 1 & & & \\
\hline
\end{tabular}




\begin{tabular}{|c|c|c|c|c|c|c|c|}
\hline 11 & Nepal Pariwar dal & 1 & 1 & 2 & 1 & - & 1 \\
\hline 12 & Rastriya Janamukti party & 1 & 1 & 2 & 1 & 1 & 2 \\
\hline 13 & Samajbadi Janata party & 1 & 0 & 1 & 1 & - & 1 \\
\hline 14 & Madhesi Janaadhikar Forum Nepal & 4 & 4 & 8 & & & \\
\hline 15 & Rastriya Janamorcha & 1 & 2 & 3 & 3 & 1 & 4 \\
\hline 16 & Nepal Comunist Party (Sayunkta) & 1 & 2 & 3 & 3 & 2 & 5 \\
\hline 17 & Nepal Janata Dal & 1 & 0 & 1 & 1 & 1 & 2 \\
\hline 18 & Nepal MajdurKisan Party & 2 & 1 & 3 & 4 & 1 & 5 \\
\hline 19 & Madhesi Janaadhikar Forum... & 0 & 1 & 1 & 41 & 13 & 54 \\
\hline 20 & Tarai madhessadbhawana party Nepal & 1 & 1 & 2 & & & \\
\hline 21 & Dalit Janajati Party & 1 & 1 & 2 & 1 & - & 1 \\
\hline 22 & Nepal Rastriya Party & 1 & 0 & 1 & 1 & - & \\
\hline 23 & Sanghiya samajbadi Party & 1 & 0 & 1 & & & \\
\hline 24 & Rastriya Madhesh Samajbadi Party & 2 & 1 & 3 & & & \\
\hline 25 & Khumbuwan Rastriya Morcha Nepal & 1 & 0 & 1 & & & \\
\hline 26 & Akhanda Nepal Party & 1 & 0 & 1 & & & \\
\hline 27 & Tharuhat Tarai Party Nepal & 1 & 1 & 2 & & & \\
\hline 28 & $\begin{array}{l}\text { Communist Party of Nepal (Marxist } \\
\text { Leninist) (CPN-ML) }\end{array}$ & & & & 5 & 4 & 9 \\
\hline 29 & Communist Party of Nepal (United) & & & & 3 & 2 & 5 \\
\hline 30 & Janamorcha Nepal & & & & 6 & 2 & 8 \\
\hline 31 & $\begin{array}{l}\text { Nepal Sadbhawana Party (Anandidevi) } \\
\text { (NSP-A) }\end{array}$ & & & & 2 & 1 & 3 \\
\hline 32 & Sanghiya Loktantrik Rastriya Manch & & & & 1 & 1 & 2 \\
\hline 33 & Nepal Loktantrik Samajbadi Dal & & & & 1 & 0 & 1 \\
\hline 34 & Chure Bhawar Rastriya Ekta Party Nepal & & & & 1 & 0 & 1 \\
\hline 35 & Independent & & & & 2 & 0 & 2 \\
\hline \multicolumn{2}{|c|}{ Total } & 169 & 159 & 328 & 404 & 197 & 601 \\
\hline
\end{tabular}

Source: Nepal Election Commission 2070.

Table 5: Women Representation in Parliament under the Four Parliamentary Elections, Nepal

\begin{tabular}{|l|c|c|c|}
\hline \multicolumn{1}{|c|}{ Year } & Total number of seats & $\begin{array}{c}\text { No of Women } \\
\text { Representation }\end{array}$ & Percent \\
\hline 1959 & 205 & 6 & 2.9 \\
\hline 1991 & 205 & 6 & 2.9 \\
\hline 1994 & 205 & 7 & 3.4 \\
\hline 1999 & 205 & 12 & 5.8 \\
\hline 2008 & 601 & 197 & 32.7 \\
\hline 2013 & 557 & 159 & 28.5 \\
\hline 2017 HOR & & & \\
\hline
\end{tabular}

Source: Nepal Election Commission, 2070. 
In the first Parliamentary election of 1959, the entire 6 women candidate lost the election. As a result of the compulsory provision of the 1990 Constitution that requires at least five percent women's candidature in the election for House of Representative the numbers of women candidates in the last three parliamentary elections held in 1991, 1994 and 1999 were gradually increased. Out of the total 205 seats only 6 (2.9\%), 7 (3.4\%) and 12 (5. 8 $\%)$ women were elected (Election Commission, 2074). Nepali women's representation in the legislative body (Legislature Parliament), however, was dramatically increased to 32.8 percent through the constituent Assembly (CA) held in 2008. In the election, 191 women leaders (33.2\%) were elected out of 575 seats, and cabinet nominated 6 women out of 26 seats, resulting to 179 women members (32.8\%) in the legislative parliament. As a result, Nepal stands on the $14^{\text {th }}$ position globally to send the women leaders in the legislature parliament. The reason behind the drastic change in the women's representation is due to the reservation of seats provided through the interim Constitution of Nepal 2007 (Election Commission of Nepal, 2074).

Table 6: Women Representation in Local Level, 2054

\begin{tabular}{|c|c|c|c|c|c|c|c|}
\hline $\begin{array}{l}\text { Local } \\
\text { level }\end{array}$ & $\begin{array}{l}\text { No of } \\
\text { Local } \\
\text { level }\end{array}$ & $\begin{array}{l}\text { No of } \\
\text { ward }\end{array}$ & $\begin{array}{l}\text { Total } \\
\text { representative }\end{array}$ & $\begin{array}{l}\text { No of } \\
\text { Reservation } \\
\text { women } \\
\text { representative }\end{array}$ & $\begin{array}{l}\text { No of women } \\
\text { elected from } \\
\text { election }\end{array}$ & $\begin{array}{l}\text { Total No. } \\
\text { of } \\
\text { Women }\end{array}$ & $\begin{array}{l}\text { \% of } \\
\text { Women }\end{array}$ \\
\hline VDC & 3913 & 35217 & 207389 & 39130 & $\begin{array}{l}\text { President }-17, \\
\text { Vice president- } 17 \text {, } \\
\text { Ward president } \\
216 \text {, Ward member } \\
-1415\end{array}$ & 40795 & 19.10 \\
\hline $\begin{array}{l}\text { Munic } \\
\text { ipaliti } \\
\text { es }\end{array}$ & 58 & 806 & 4668 & 1177 & $\begin{array}{l}\text { Mayor - 0, } \\
\text { Vice Mayor- 0, } \\
\text { Members -4 }\end{array}$ & 1181 & 0.5 \\
\hline$\overline{\mathrm{DDC}}$ & 75 & $\begin{array}{l}927 \\
\text { (Ilaka) }\end{array}$ & 1527 & 75 & $\begin{array}{l}\text { Chairman - } 0 \text {, Vice } \\
\text { chairman- } 1 \text { and } \\
\text { Members - } 9\end{array}$ & 85 & 0.03 \\
\hline Total & & & 213584 & & 1679 & 42061 & 19.67 \\
\hline
\end{tabular}

Source: Mirest Nepal (Mahim Limu), Nepalko Sthaniya Sashan Ain, 2070, p- 92.

Kathmandu, Nepal.

Women representation in local level, 2054, in VDC level, out of total 40795, total 39130 women reservation representation, Numbers of women elected from election 17 president, 17 vice president, 216 ward president and 1415 ward members. Similarly, in Municipality level, out of total 1181only 4 members are elected. In District Development Committee, out of 85 elected women, only one vice chairman and 9 members are elected. 
Table 7: Gender Inclusion in Local Government in Nepal (elected Mayor and Deputy Mayor in Metropolitan and sub metropolitan cities, 2074)

\begin{tabular}{|l|c|c|c|}
\hline Elected Post & Male & Female & Total \\
\hline Mayor & 15 & 2 & 17 \\
\hline Deputy Mayor & 0 & 17 & 17 \\
\hline Total & 15 & 19 & 34 \\
\hline
\end{tabular}

Source: Election Commission of Nepal, 2074.

Gender inclusion in local government in Nepal (elected Mayor and Deputy Mayor in Metropolitan and sub metropolitan cities, 2074). In total 17 Mayors, nearly almost (15) are males Mayors and only 2 re female Mayors. Similarly, all 17 are Deputy Mayors. In total 34, males are 15 and females are 2 are participating in local government body.

Women in the 2008 Constituent Assembly

As a result of the strong provisions in the Interim Constitution 2007 that favored more participation of women in politics, the Constituent Assembly election of 2008 became historic as approximately 53 percent of voters were estimated to be women out numbering men voters (Kanel, 2014). The Constitution made a significant contribution in terms of gender equality as a 33\% quota had been allocated for women representatives ranking Nepal $16^{\text {th }}$ out of 140 countries in terms of the percentage of women in national parliament (UNDP, 2010).

\begin{tabular}{|c|c|c|}
\hline \multicolumn{3}{|c|}{$\begin{array}{l}\text { Table 8: Women's Participation in Various Committees of the first Constituent Assembly } \\
\text { (2065 B.S.-2070 B.S.) }\end{array}$} \\
\hline $\begin{array}{l}\text { Different Committees of the first } \\
\text { Constituent Assembly (CA) }\end{array}$ & $\begin{array}{l}\text { Number of Women in } \\
\text { the committee }\end{array}$ & $\begin{array}{l}\text { Women chairing } \\
\text { the committee }\end{array}$ \\
\hline Constitutional Committee & 16 & \\
\hline $\begin{array}{l}\text { Fundamental Rights and Directive } \\
\text { Principles }\end{array}$ & 15 & Binda Pandey \\
\hline Minority and Marginalized Community Rights & 17 & \\
\hline State Restructuring and State Power Sharing & 12 & \\
\hline $\begin{array}{l}\text { Committees for determining the pattern of } \\
\text { Administrative Organs }\end{array}$ & 11 & \\
\hline $\begin{array}{l}\text { Committee for Determination of State } \\
\text { Government }\end{array}$ & 12 & \\
\hline Jurisdiction & 16 & \\
\hline Committee for Structure of Constitutional Body & 15 & \\
\hline $\begin{array}{l}\text { Natural Resources, Financial Rights and Revenue } \\
\text { Sharing }\end{array}$ & 7 & Amrita Thapa Magar \\
\hline
\end{tabular}




\begin{tabular}{|l|l|l|}
\hline $\begin{array}{l}\text { Committee for determining the basis of cultural } \\
\text { and social solidarity }\end{array}$ & 19 & Nabodita Chaudhary \\
\hline National Interest Conservation & 9 & \\
\hline Civil Relations & 15 & Meena Pandey \\
\hline $\begin{array}{l}\text { Civil Concept Compilation and } \\
\text { Coordination }\end{array}$ & 14 & \\
\hline $\begin{array}{l}\text { Capacity Building and Source } \\
\text { Management }\end{array}$ & 18 & 4 \\
\hline Total 14 & 196 & \\
\hline
\end{tabular}

Sources: Election Commission of Nepal, 2074

Women in the 2013 Constituent Assembly

In 2013 a new election was held, under the chairpersonship of the Supreme Court Judge Mr. Khil Raj Regmi, following the 2012 dissolution of the Constituent Assembly. Compared to the 2008 election, fewer women were elected in the 2013 CA election. The major political parties saw losses in the number of women candidates from 96 in 2008, to 77 in the 2013 CA election. However, the percentage of women in the CA remained 30 per cent out of 601 members (Dhungana, 2014) mainly because of the constitutional provisions of proportional representation in the electoral system.

\begin{tabular}{|l|l|l|l|}
\hline \multicolumn{2}{|l|}{$\begin{array}{l}\text { Table 9: Table showing the elected women representatives in local elections in } \\
\text { different province }\end{array}$} \\
\hline Provinces & Political parties & Male & Female \\
\hline \multirow{3}{*}{ Province 1 } & Nepali Congress (NC) & 1204 & 794 \\
\cline { 2 - 4 } & Unified Marxist Leninist (UML) & 1849 & 1370 \\
\cline { 2 - 4 } & Maoist Centre (MC) & 317 & 189 \\
\cline { 2 - 4 } & Sanghiya Samajwadi (SS) & 79 & 61 \\
\cline { 2 - 4 } & Others & 111 & 68 \\
\hline \multirow{3}{*}{ Province 2 } & Nepali Congress (NC) & 1042 & 689 \\
\cline { 2 - 4 } & Unified Marxist Leninist (UML) & 711 & 538 \\
\cline { 2 - 4 } & Maoist Centre (MC) & 665 & 463 \\
\cline { 2 - 4 } & SanghiyaSamajwad (SS) & 610 & \\
\hline
\end{tabular}

\begin{tabular}{|l|l|l|l|}
\hline & Others & 857 & 585 \\
\hline \multirow{4}{*}{ Province 3 } & Nepali Congress (NC) & 1093 & 673 \\
\cline { 2 - 4 } & Unified Marxist Leninist (UML) & 1749 & 1278 \\
\cline { 2 - 4 } & Maoist Centre (MC) & 522 & 349 \\
\cline { 2 - 4 } & Sanghiya Samajwadi (SS) & 104 & 58 \\
\cline { 2 - 4 } & Others & 0 & 0 \\
\hline Province 4 & Nepali Congress (NC) & 1053 & 711 \\
\cline { 2 - 4 } & Unified Marxist Leninist (UML) & 950 & 702 \\
\cline { 2 - 4 } & Maoist Centre (MC) & 208 & 143 \\
\hline
\end{tabular}




\begin{tabular}{|l|l|l|l|}
\cline { 2 - 4 } & Sanghiya Samajwad (SS) & 0 & 0 \\
\cline { 2 - 4 } & Others & 104 & 61 \\
\hline Province 5 & Nepali Congress (NC) & 948 & 659 \\
\cline { 2 - 4 } & Unified Marxist Leninist (UML) & 1133 & 810 \\
\cline { 2 - 4 } & Maoist Centre (MC) & 868 & 367 \\
\cline { 2 - 4 } & Sanghiya Samajwad (SS) & 139 & 105 \\
\cline { 2 - 4 } & Others & 257 & 170 \\
\hline Province 6 & Nepali Congress (NC) & 643 & 401 \\
\cline { 2 - 4 } & Unified Marxist Leninist (UML) & 862 & 554 \\
\cline { 2 - 4 } & Maoist Centre (MC) & 669 & 469 \\
\cline { 2 - 4 } & Sanghiya Samajwad (SS) & 0 & 0 \\
\cline { 2 - 4 } & Others & 76 & 44 \\
\hline Province 7 & Nepali Congress (NC) & 943 & 624 \\
\cline { 2 - 4 } & Unified Marxist Leninist (UML) & 943 & 692 \\
\cline { 2 - 4 } & Maoist Centre (MC) & 313 & 221 \\
\cline { 2 - 4 } & Sanghiya Samajwad (SS) & 0 & 0 \\
\cline { 2 - 4 } & Others & 64 & 41 \\
\hline
\end{tabular}

Source: Election Commission of Nepal, 2074

Though a woman representative has been able to retain the position of President (1), difference of $98.16 \%: 8.13 \%$ (See table 5). This shows that power structures and hierar chystill 17 in the House of Representatives, 6 in the Provincial Assembly and 21 in National Assembly, the ratioof male and female elected representatives still shows a huge percentage gap prevail in Nepali politics.

\begin{tabular}{|c|c|c|c|c|c|c|c|}
\hline Gender & $\begin{array}{l}\text { House of } \\
\text { Representative }\end{array}$ & $\begin{array}{l}\text { Provincial } \\
\text { Assembly }\end{array}$ & $\begin{array}{l}\text { National } \\
\text { Assembly }\end{array}$ & President & $\begin{array}{l}\text { Vice- } \\
\text { President }\end{array}$ & Total & Percent \\
\hline Male & 313 & 159 & 35 & & 1 & 508 & 91.86 \\
\hline Female & 17 & 6 & 21 & 1 & & 45 & 8.13 \\
\hline $\begin{array}{l}\text { Grand } \\
\text { Total }\end{array}$ & 330 & 165 & 56 & 1 & 1 & 553 & 100 \\
\hline
\end{tabular}

\section{Conclusion}

From Rana rule through the Panchayat era to the Maoist insurgency and the Federal Democratic Republic, Nepal has undergone lengthy and massive socio-political uncertainties and changes. However, Nepali women have constantly challenged the patriarchy in all its dimensions. They initiated a movement for their rights—one that has been largely ignored in the literature-more than 100 years ago under the leadership of 
Yogmaya Neupane, a movement that continues today. Even though the road for women towards political participation has not been easy, they have been quite successful over the last decade in securing their rights. Achieving the 33 percent quota in the parliament and other political and bureaucratic structures is an example of suchsuccess.

Though the Constitution of 1990 brought much hope for the country's political transformation and guaranteed considerable political rights, civil liberties, and individual freedom, it was only able to introduce a few changes regarding gender-discriminatory laws. After the signing of the CPA and the promulgation of the Interim Constitution, the onethird representation in government structures for women was secured. Consequently, the motivation for women to engage in the election process also increased. The Constituent Assembly election of 2008 became historic as women's participation outnumbered menan example of such motivation.

The Constitution of 2015 promised at least 33\% of women's participation in all the State operations. At the local level, 41 percent of newly elected officialswere women along with 34 per cent of Provincial assembly seats reserved for women. However, despite the promise of including women's representation in the state restructuring, women have been denied political power at the local level. Women candidates have been elected in the Parliament simply to fulfill the quota of including women representatives. As noted above, many operational problems in the daily execution of Parliamentary duties persist due to entrenched discrimination.

The women of Nepal are still not freed from the burden of living in a patriarchal society. Too often their capacity to participate in Parliament at quota levels has been questioned, rather than holding up for scrutiny the forms of discrimination and lack of opportunities that have underprepared women for equal participation. The influence of women in decision-making and constitutionbuilding process remains limited. They initiated a movement for their rightsone that has been largely ignored in the literature. Though the Constitution of 1990 brought much hope for the country's political transformation and guaranteed considerable political rights, civilliberties and individual freedom, it was only able to introduce a few changes regarding gender-discriminatory laws. After the signing of the CPA and the promulgation of the Interim Constitution, the one-third representation in government structures for women was secured. Consequently, the motivation for women to engage in the election process also increased. The Constituent Assembly election of 2008 became historic as women's participation outnumbered men-an example of suchmotivation. The Constitution of 2015 promised at least 33\% of women's participation in all the 
State operations. At the locallevel, 41 percent of newly elected official swere women along with 34 per cent of Provincial assembly seats reserved for women. However, despite the promise ofincluding women's representation in the State restructuring, women have been denied political power atthe local level. Women candidates have been elected in the Parliament simply to fulfill the quota of including women representatives. As noted above, many operational problems in the daily execution of Parliamentary duties persist due to entrenched discrimination. The women of Nepal are still not freed from the burden of living in a patriarchal society. Too often their capacity to participate in Parliament at quota levels has been questioned, rather than holding up for scrutiny the forms of discrimination and lack of opportunities that have underprepared women for equal participation. The influence of women in decision-making and constitution-building process remains limited. Though women have become successful in acquiring higher positions (e.g., President of Nepal, earlier Chief Justice of Supreme Court and Speaker of the Parliament), achievements not even possible to imagine two decades ago, the achievements attained thus far are not enough. Continued, concerted action among all actors is essential.

Almost 90 percent respondents of study areas of both districts are affiliated to political parties before they were elected in local government. Almost 50 percent people of both Jhapa and Lalitpur district have knowledge of gender inclusion. The mass media is most effective source to dissemination of the information to the general public but it has still lacking to bring the more effective awareness program activities. However, majority of the people of both districts have knowledge of different laws, acts, and policy programs related to gender inclusion in local government. But minority caste/ethnic groups have excessive low knowledge comparing to other caste/ethnic groups. There is no difference between rural municipality and municipality and metropolitan city to obtain the knowledge. The people with Secondary level education have more knowledge on the issue comparing to people with primary level education and it is the usual and natural phenomenon. As sex ratio 145 female in 100 middle-aged group below 39 years are affiliated in political before they elected in local government but females are more affiliated than male. In the case of districts and sex, there is no association to affiliation in political and district location and sex

\section{Acknowledgments}

The authors would like to acknowledge the Feminization of Agriculture, Transition and Rural Employment (FATE) research project funded by the Swiss National Science Foundation and Swiss Agency for Development and 
Cooperation (SDC) for supporting this research. The author is grateful to all the respondents for their valuable information. I would also like to express my sincere gratitude of Professor Dian Fox, the editor in chief of the journal for her time and efforts to correct English and providing text in appropriate places to make article more interesting.

\section{References}

ADB [Asian Development Bank]. (2017). Country poverty analysis (detailed). Nepal: Asian Development Bank.

Asia Foundation, T [The Asia Foundation]. (2018). Nepal's locally elected women representatives: exploratory study of needs and capacity. Nepal: Australian Aid and The Asia Foundation.

Aziz, B. (2001). Heir to a silent song: two rebel women of Nepal. Kathmandu: Centre for Nepal and Asian Studies, Tribhuvan University.

Bhattarai-Ghimire, A., \&Upreti, B. R. (2008). Conflict induced displacement: an emerging phenomenon of internal migration in Nepal. In K. N. Pyakuryal, B. R. Upreti, \& S. R. Sharma, Nepal: transition to transformation (pp. 101-139). Kathmandu: Human and Natural Resources Studies Center and South Asia Regional Coordination Office of NCCR North-South.

Bushell, B. (2008). Women entrepreneurs in Nepal: what prevents them from leading the sector? Gender and Development, 16:3, 549-564.

CEDAW [Convention on the Elimination of all Forms of Discrimination Against Women]. (2018). Civil society's shadow report for pre-session of 6 th periodic report on CEDAW convention. UN Women and Government of Denmark.

Dahal, G. (2017). Constitution of Nepal and political development: adaptation and challenges of implication. Janapriya Journal of Interdisciplinary Studies, vol.6, 148-159.

Dhungana, R. K. (2014). Nepali hindu women's thorny parth to liberation. Journal of Education and Research, Vol.4, No.1, 39-57.

Einsiedel, S. V., Malone, D. M., \& Pradhan, S. (2012). Nepal in transition: from people's war to fragile peace. USA: Cambridge University Press.

FWLD [Forum for Women, Law and Development]. (2016). Legal analysis of citizenship law of Nepal: a comparative study of the Nepal Citizenship Act, 2006 with the constitution, precedents, international human rights obligation and best practices. Forum for Women, Law and Development.

Gautam, S., Banskota, A., \&Manchanda, R. (2001). Where there are no men: women in the maoist insurgency in Nepal. In K. Visweswaran, Perspectives on modern south asia: a reader in culture, history and representation (pp. 340-348). West Sussex, United Kingdom: Blackwell Publishing Ltd.

Ghale, Y. (2008). Scoping study on women's leadership in the agriculture sector inNepal.

Kathmandu: Women Organizing for Change in Agriculture and NRM (WOCAN). GoN [Government of Nepal]. (2015). The constitution of Nepal 2072 (2015). Kathmandu:

Government of Nepal.

GoN [Government of Nepal]. (2007). The interim constitution of Nepal 2063 (2007).

Kathmandu: Government of Nepal.

Gurung, N. (2011). Local democracy in the political transition of Nepal. Alliance for Social Dialogue, Southasia Institute of Advanced Studies.

Hachhethu, K., \&Gellner, D. N. (2010). Nepal: trajectories of democracy and restructuring of the State. In P. Brass, Routledge Handbook of South Asian Politics (pp. 131-46). London and New York: Routledge. 
Haug, M., Aasland, A., \&Dahal, D. R. (2009). Patterns of socio-political participation in Nepal and implications for social inclusion. Forum for Development Studies, 36:1 , 105-136.Abbott, P., Haerpfer, C., Wallace, C., (2008). Women in Rwandan politics and society. International Journal of Sociology, Ruwanda.

Acharya, Meena (2003): Towards Conflict Transformation in Nepal: Recent Trends in

ADB, (2010). Overview of Gender Equality and Social Inclusion in Nepal, (2003 b). ADB, Published by All Right Reserved 2010.

ADB, (2015). Gender Review of National Energy Policies and Programmes (2015), Sri Lanka.

Angela E.V. King, (2002). GENDER MAINSTREAMING AN OVERVIEW, United Nations, New York.

Anne H., (2015). The Role of Local Governments Promoting Gender Equality for Sustainability, UCLG, Paris

Armendáriz, B., (2010). The Economics of Microfinance. Cambridge: MIT Press.

Audit of the Ministry of Local Development" conducted by the "SAHAVAGI" team for the Ministry of Women Children and Social Welfare and MGEP/UNDP, Kathmandu, Nepal.

Bakker, F. S., \&Kartner, F. (2013). Excuustruus of EchteTopvrouw. Over de wenselijkheid van vrouwenquota in het bedrijfsleven. Elsevier.

Bansari K. (2020). Money, pedigree, sexism and social norms keep Sri Lanka's largest electoratethe country's women - out of politics. Diplomatic Magazine, Sri-Lanka. September 25.

Barriteau, Eudine; Connelly, Patricia; Parpart, Jane L (2000). Theoretical Perspectives on Gender and Development. Ottawa: International Development Research.

Beaman, L.; Chattopadhyay, R.; Duflo, E.; Pande, R.; Topalova, P., (2009). "Powerful women: does exposure reduce bias". Quarterly Journal of Economics. Oxford Journals. 124 (4): 1497-1540. Oxford, University Press.

Bhavnani, R.R., (2009). "Do electoral quotas work after they are withdrawn: Evidence from a natural experiment in India". American Political Science Review .Cambridge Journals.103 (1): 23-35. Cambridge University press.

Boserup.E., (2011). "Women's role in economic development", in Visvanathan, Nalini; Duggan, Lynn; Nisonoff, Laurie; et al., The women, gender and development reader (2nd ed.), Halifax

Bourdieu, P. (2001). Masculine Domination. Cambridge Polity Press. Election Manifestos of Nepali Congress, NCP-UML, NCP (Maoists) Election Commission's Website

Carmichael, S.; Dilli, S.; R., Auke (2017). "Women in Parliaments: World and Regional Averages". Cambridge University.

Carmichael, S.; Dilli, S.; Rijpma, A. (2013). "Women in Parliaments: World and Regional Averages". Cambridge University.

CBS, (2011). Population Census Report. National Planning Commission Secretariat, Ramshah Path, Kathmandu.

Center for American Women and Politics (2020). New State Grades on the Economic Status of Women. The Heritage Society | 1100 Bagby Street | Houston, Texas 77002 | 713-6551912 | info@heritagesociety.org.

Chattopadhyay, R.; Duflo, E., (2004). "Women as Policy Makers: Evidence from a Randomized Policy Experiment in India". Econometrica.Wiley.72 (5): 1409-1443. JSTOR Conference (11-17 December 2002)” Bangkok.

Cox A., (2010). Women in Public life in the Maldives: Situation Analysis. UNDP, Maldives 
Davidson-S., Louise K., (2006). "Implementation of political party gender quotas: evidence from the German Länder 1990-2000". Party Politics. Sage.12 (2): 211-232.

DFID/WB, (2005). “Citizens With (Out) Rights: Nepal Gender and Social ExclusionAssessment”, Summary Report, Kthmandu, Nepal.

Dychtwald, Z., (2018). Young China: How the Restless Generation Will Change Their Country and the World. China, St. Martin's Press. .

Feng, X., (2013). "Women's Work, Men's Work: Gender and Tourism among the Miao in Rural China". Anthropology of Work Review. 34 (1): 2-14.

Frank, A. G., (1969). Capitalism and underdevelopment in Latin America: historical studies of Chile and Brazil (Rev. and enl. ed.). New York.

GESI Working Group, (2017). Gender Equality and Social Inclusion Working Group, International Development Partners Group, Nepal.

Ghimere D. (2001). Women's Political Participation and Challenges. Gender and Democracy in Nepal. Center Department of Home Science Women's Studies Program, Tribhuvan University.

GMG Nepal (1980). Sixth Five Year Plan 1980-1985. National Planning Commission. Singhdurbar, Kathmandu.

Government of Nepal (2007). Inclusion of Women in Local Government. Ministry of Local Development. Sighdurbar, Kathmandu,

Government of Nepal (2007). Interim Constitution of Nepal. Singha Durbar, Kathmandu.

Government of Nepal (2028). Marriage Registration Act, 2028. Ammendment, 2072. Council of ministry, Singhdurbar, Kathmandu.

Government of Nepal (2063). KarmacharySanchayakosh Act, 2063. Ministry of Finance. Singhadurbar, Kathmandu.

Government of Nepal (2063). Muluki Ain, $11^{\text {th }}$ amendment, 2063. Singh Durbar, Kathmandu.

Government of Nepal (2064). Upper House Parliament Secretariat Related Act, 2064. Council of Ministry, Singhdurbar, Kathmandu.

Government of Nepal (2068). Civil Rights Act, 2012 (ammendmented in 2068). Ministry of Home and Affairs. Singhdurbar, Kathmandu.

Government of Nepal (2072). Amedment of KamaiyaElemination Act, 2072. Ministry of Labour, Sighdurbar, Kathmandu.

Government of Nepal (2072). Public Act (Criminal and Punishment Act, 2027) ammendment 2072. Ministry of Home. Singhdurbar, Kathmandu.

Government of Nepal (2073). Election Commission Act, 2073. Article 42. Council of Ministries. Singhdurbar, Kathmandu.

Government of Nepal (2073). Local Level Election Act, 2073. Council of Ministry, Singhdurbar, Kathmandu.

Government of Nepal (2073). Political Parties Related Act, 2073. Councile of Ministry. Singhdurbar, Kathmandu.

Government of Nepal (2074). National Women Commission Act, 2074. Council of Ministry. Singhdurbar, Kathmandu.

Government of Nepal (2074). Social Security on the Basis of Contribution Act, 2074. Council of Ministry, Singhdurbar, Kathmandu.

Government of Nepal, (2007). The Interim Three Years Plan 2007- 2010. National Planning Commission of Nepal, Singhdurbar, Kathmandu.

Government of Nepal, (2016). Approach Paper of 14 th Three Year Plan 2016-2019. National Planning Commission of Nepal. Singhdurbar, Kathmandu. 
Government of Nepal, (1999). Local self governance act. National Planning Commission. Sighadurbar, Kathmandu.

Government of Nepal, (2015). Sustainable Development Goals, 2016- 2030: National

Government of Nepal, (2048). Child related Act, 2048. Ministry of Child and... Singhdurbar, Kathmandu.

Government of Nepal, (2064). Human Trafficking and Transportation Controll Act, 2064. Ministry of Home and Affaires. Singhdurbar, Kathmandu.

Government of Nepal, (2064). Upper House Parliament Members Secratoriate Office Related Act 2064. Council of Ministry, Singhdurbar, Kathmandu.

Government of Nepal, (2074). Local Government Election. Election Commission of Nepal. Kathmandu.

Government of Nepal, (2074). Local Government Mobilization Act, 2074. Council of Ministry, Singhdurbar, Kathmandu.

Government of Nepal, (2074). Parliamentary Council Member election 2074: Election Result Book, First Inclusive Election System. Election Commission of Nepal. Kantipath, Kathmandu.

Government of Nepal, (2074). Province Council member election 2074: Election Result Book, First Inclusive Election System. Election Commission of Nepal. Kantipath, Kathmandu.

Government of Nepal. (1015). Constitution Bill of Nepal, Constitution Drafting Committee Constituent Assembly Secretariat, Singha Durbar. Kathmandu

Government of Nepal. (2072). Gali and Beijoti Act 2016 (Ammendment 2072). Ministry of Home and Afire. Singhdurbar, Kathmandu.

Government of Nepal. (2074).

Government of Nepal. (2074). Local Election, 2074: Election Result Book. Province No. 1. Election Commission of Nepal, Kantipath, Kathmandu.

Government of Nepal. (2074). Local Election, 2074: Election Result Book. Province No. 2. Election Commission of Nepal, Kantipath, Kathmandu.

Government of Nepal. (2074). Local Election, 2074: Election Result Book. Province No. 4. Election Commission of Nepal, Kantipath, Kathmandu.

Government of Nepal. (2074). Local Election, 2074: Election Result Book. Province No. 5. Election Commission of Nepal, Kantipath, Kathmandu.

Government of Nepal. (2074). Local Election, 2074: Election Result Book. Province No. 6. Election Commission of Nepal, Kantipath, Kathmandu.

Government of Nepal. (2074). Local Election, 2074: Election Result Book. Province No. 7. Election Commission of Nepal, Kantipath, Kathmandu.

Government of Nepal., (2074). MulukiDewani Act, 2074. Ministry of Home and Affaires. Singhdurbar, Kathmandu.

Government of Spain, (2015). United Cities and Local Governmets. Barcelona, Spain

Guo, X., (2008). Women's Political participation in China. The. China.

Gurung, H. (2005). "Social Exclusion and Maoist Insurgency" in Sarah Webster and Om Gurung (eds.) ILO Convention No. 169 and Peace Building inNepal. NEFIN and ILO/Nepal: Kathmandu.

Gurung, Om, (2009). Social Inclusion: Policies and Practices in Nepal.

Hassim, S., (2009), "Perverse consequences: The impact of quotas for women on democratization in Africa" UK, Cambridge University press.

Hassim, S., (2010). "Perverse consequences: The impact of quotas for women on democratization in Africa" UK, Cambridge University press. 
Hassim, S., (2017). Women in Parliaments: World Classification. UK, Cambridge University press. Henderson, S. L.; Jeydel, A. S. (2014). "Women and International Politics". Women and Politics in a Global World. Oxford University Press.

Hillary, Clinton (2012). Gender Equality and Female Empowerment Policy. USAID

His Majesty's Government (HMG) (1990). Constitution of the Kingdom ofNepal.

His Majesty's Government. (2038/02/09). Nepal Rajpatra, Section 31, Additional Issue 4, Part 4. Kathmandu: His Majesty'sGovernment.

His Majesty's Government. (2043/02/18). Nepal Rajpatra, Section 36, Additional Issue 11, Part 4. Kathmandu: His Majesty'sGovernment.

HMG Nepal (1986). The Seventh Five Year Plan 1986- 1990. National Planning Commission of Nepal. Singhdurbar, Kathmandu.

HMG Nepal (1997). The Ninth Five Year Plan 1997- 2002. National Planning Commission of Nepal, Singhdurbar, Kathmandu.

HMG Nepal (2002). The Tenth Five Year Plan 2002-2007. National Planning Commission of Nepal. Singhdurbar, Kathmandu.

HMG Nepal (2092). The Eight Five Year Plan 1992-1997. National Planning Commission of Nepal, Singhdurbar, Kathmandu.

HMG, (1999). Local Self-Governance Act, 2055 B.S. HMG, Nepal.

HMG, (1999). Local Self-Governance Regulation, 2056 B.S., Published by Nepal Gazette, 30 Dec. 1999.

HMG/N, Ministry of Women, Children and Social Welfare, Mainstreaming Gender Equity Programme (MGEP), UNDP, Kathmandu, Nepal.

Hope for Women Maldives NGO, (2012). Shadow Report to the Committee on the Elimination of Discrimination against Women (2012), p 4 and 6

Howell, J., (2008). "The Representation of Women in Rural Politics. Via Journal of Contemporary, China.

ILO, (1976). Employment, growth, and basic needs: a one-world problem: International Labour Office. Geneva.

ILO, (2000). ABC of Women Worker's Rights and Gender Equality. Geneva

Institute for Integrated Development Studies (IIDS) (1993). The second parliamentary election: A study of the emerging democratic process in Nepal. Kathmandu: Institute for Integrated Development Studies.

International Conference Population and Development, (1994). Eliminating Human Traffinking and Prostitution. Cairo (ICPD 1994) PP. 46.

International Models Project on Women Rights. (2015). Current legal framework: "Participation in policy formation and implementation in Romania". Romania

Inter-Parliamentary Union, (2014). “Women In National Parliaments": http://www.ipu.org/wmn-e/classif.htm

Irene T., (1990). Persistent Inequalities: Women and World Development. Oxford University Press.

Iwanaga, K., (2003). Women's political representation and electoral system in Japan'sInternational Conference Women and Politics in Asia. Conference Paper. Halmstad University, Japan

Jinghan, Z., (2014). "Institutionalization of the authoritarian leadership in China: a power succession system with Chinese characteristics". Contemporary Politics, 20 (3): 294-314. viaResearch Gate.

Kabeer, N. (1994). Reversed Realities, Gender Hierarchies in Development Though, London: Verso 
Kathmandu: Law Book Management Committee.

Krauss, E. S.; Pekkanen, R. J., (2011), "The köenkai: origin and development of a votemobilization machine". The rise and fall of Japan's LDP: political party organizations as historical institutions, Ithaca: Cornell University Press,

Lama, S., Khakurel, D., Agrawal, K., \& Shrestha, M. (2011). Women members of the Constituent Assembly: A study on contribution of women in constitution making in Nepal. Kathmandu: Women's Caucus, Constituent Assembly Secretariat, Nepal Law Society and International Institute for Democracy and Electoral Assistance.

Limbu M. (2070). NepalkoSthaniyaSashan: SthaniyaNikayamaMahilaSahabhagitaChunautiharuP. 92. Mirest Nepal, Kathmandu Nepal.

Local Election, 2074: Election Result Book. Province No. 3. Election Commission of Nepal, Kantipath, Kathmandu.

Merchant, C., (1980). The Death of Nature: Women, Ecology, and the Scientific Revolution: a Feminist Reappraisal of the Scientific Revolution (First ed.). San Francisco: Harper \& Row.

Mies, M.; Bennholdt-T.V.; Werlhof, C. V., (1988). Women: The Last Colony. London: Zed Books.

Miller, David E,. (2011). "Lebanon's Clerics Attack Domestic Violence Law". Social Institutions. Lebanon

MOHP/HMG (2005). "NEPAL Report on ICPD at Ten”, Ministry of Health and

MOPE/HMG (2002). "Nepal Country Report”, Fifth Asian and Pacific Population

Moser, C., (1993). Gender Planning and Development. Theory, Practice and Training. New York: Routledge. p. 3.23

Moser, Caroline O.N., (1995). Gender planning and development: theory, practice and training (Reprint. ed.). Oxford University Press.

MWCSW/HMG/MGEP/UNDP (2001). "Engendering Nepalese Civil Service with Ministry of Women, Children and Social Welfare, Kathmandu, Nepal

MWCSW/HMGN/MGEP/UNDP (2002), “Gender Assessment in the Health Sector”,Dhumbarai, Kathmandu. Nepal

National Planning Commission, (2007). The Tenth Plan. Kathmandu: NPC National Planning Commission, Nepal. 2008. Three-year Interim Plan 2007 -

NEFAS/FES, Kathmandu

Nepal Communist Party (Amale) (2074). Party Election Manifesto. Party Office, Dhumbari Kathmandu, Nepal.

Nepali Congress Party, (2017). Party Election Manifesto: Election of Upper House Parliament Members and Local Level. Party Office, Kathmandu, Nepal

Nepali Congress Party, (2017). Party Election Manifesto: Election of Upper House Parliament Members and Local Level. Party Office, Sanepa, Lalitpur, Nepal

NPC, (1997). Ninth Plan, 1997-02, Kathmandu: NPC

NPC, (1980). Sixth Plan, 1980-85, Kathmandu: NPC

NPC, (2007). Tenth Plan, 2007-12, Kathmandu: NPC,

Nussbaum, M., ed. (1995). The quality of life a study prepared for the World Institute for D UN., (2013), Gender Equality and Economic Growth, is there a Win-Win? IDS Working Paper Volume No. 417

OIC, (2014). website, http://www.oic-ci.org/oicv2/page/?p_id=52\&p_ref=26\&lan=en,

Paxton, P.; Hughes, M. M.; Kunovich, S. L. (2007). "Gender in politics". Chicago University Journals 33 (1): 263-284. 
Paxton, Pamela; Hughes, Melanie M.; Kunovich, Sheri L. (2014). "Gender in politics". Annual Review of Sociology- 33 (1): 263-284. Stockholm University.

Pearce, S.; Amin. T. B., (1976). Unequal development: an essay on the social formations of peripheral capitalism. Hassocks: Harvester Press.

Pikkala, S., (2000). Representations of women in Finnish local government: effects of the 1995 gender quota legislation. Paper presented at the European Consortium on Political Research Joint Sessions of Workshops, Copenhagen

Quinn Ingrid., (2010). Women in Public Life in Maldives: Situation Analysis. UNDP Maldives.

Rathgeber, Eva M., (1990). “WID, WAD, GAD: Trends in Research and Practice.” The Journal of Developing Areas.

Razavi, Shahrashoub; Carol M. (1995). "From WID to GAD: Conceptual Shifts in the Women and Development Discourse".

Razavi, Shahrashoub; Miller, C. (1995). "From WID to GAD: Conceptual shifts in the Women and Development discourse". United Nations Research Institute, Oxford University Press.

Reeves, H., (2000). Gender and Development: Concepts and Definitions Brighton. p.18.

Robert C., (1987). Gender and power: society, the person, and sexual politics. Stanford University Press.

Royal Government of Bhutan, (2011). Study report on Women's Political Participation in 2011 local government election. Institute for Management Studies. Bhutan.

Sacchet, T., (2008). "Beyond numbers: the impact of gender quotas in Latin America". International Feminist Journal of Politics. 10 (3): 369-386.

SanghiyaSamajbadi Forum Nepal., (2017). Party Menifesto: election of Upper House and Local Level, Party Office, Balkumari, Kathmandu

Shamim I., Kumari R., (2002). Gender and local governance a New Discourse in Development. Centre for Social Research, New Delhi.

Shamim I., Kumari R., (2002). Gender and local Governance a New Discourse in Development. Centre for Women and Children Studies Dhaka.

Shapiro, I.; Stokes, S. C.; Wood, E. J.; Kirshner, A. S., (2011). Political representation of Women in Rwanda: UK, Cambridge University Press,

Shrestha, S.L, (1994). Gender Sensitive Planning What, Why and How in Nepal. Women Awareness Centre Nepal. Office Support Service Centre Press, Kathmandu.

Sijapati, D. B. \&Subedi, G., (2020). Impact of Gender Inclusion in Local Government: A study Based on Lalitpur and Jhapa Districts. PatanPragya, Vol.7, No.1, TUTA Unit, Patan Multiple Campus.

Sijapati, D. B. (2013). The Status of Gender Inclusion in Community Forestry of Nepal: A Case Study of Lalitpur District. An Unpublished Thesis of M. Phil, CDPS, T.U.

Steinhauer, J. (2011). "More women in Senate, but seats are at risk". New York Times Journal. New York.

Subedi, G., (2011).

UCLG (2015). The role of local governments promoting gender equality for sustainability. Women Leadership and Development, Standing Committee on Gender Equality. Paris

UN, (1983). Establishment of the Committee on the Elimination of Discrimination against Women, CEDAW

UN, (1994). International Conference on Population and Development, Cairo; adoption of the Programme of Action

UN, (1995). Fourth World Conference on Women, Beijing; adoption of the Platform of Action.

UN, (1995). World Summit for Social Development. Cophegian, Africa 
UN, (2000). UN Millennium Summit (Millennuim Development Goals.

UN, (2007). Population Policy: world Population Policy (2007). Department of Economic and Social Affaires Population Devision, UN, New York, 2008.

UN, (2013). The World Declaration on Women in Local government. The Global Conference of Local Elected Women. Paris.

UNDP, (2015). The target is to eliminate gender disparity in primary and secondary education at all levels by 2015. UN office, Maldives

UNDP, (2000). Inclusive Democracy Secures Rights. Human Development Report. Human Development Report Office, New York

UNDP, (2016). Human Development Report 2016: Human Development for Everyone, p.12

UNESCO, (2017). Social and Human Sciences. Geneva

UNICEF, (2017). Women and children: the double dividend of gender equality, United Nation, New York.

UNICEF. (2011). Promoting Gender Equality: An Equity-based Approach to Programming" Specific Reference to Promotion and Entry in Administrative Services”, Kathmandu, Nepal.

United Nations (2015). "Women's Rights in the Middle East and North Africa - Lebanon High Commissioner for Refugees, Lebanon.

USAID. (2018). FACT Sheet; Gender Equality, Female Empowerment, and Social Inclusion. New York.

Visvanathan N., (2011). The women, gender and development reader (2nd ed.). New York: Fanwood Publishing Zed Books Ltd. Distributed. 